\title{
Protective activity of Panduratin A against Thioacetamide-induced oxidative damage: demonstration with in vitro experiments using WRL-68 liver cell line
}

\author{
Suzy M Salama', Ahmed S AlRashdi', Mahmood A Abdulla', Pouya Hassandarvish ${ }^{1}$ and Mehmet Bilgen²*
}

\begin{abstract}
Background: Chalcone Panduratin A (PA) has been known for its antioxidant property, but its merits against oxidative damage in liver cells has yet to be investigated. Hence, the paper aimed at accomplishing this task with normal embryonic cell line WRL-68.

Methods: PA was isolated from Boesenbergia rotunda rhizomes and its 2,2-diphenyl-1-picrylhydrazyl (DPPH) scavenging and ferric reducing power (FRAP) activities were measured in comparison with that of the standard reference drug Silymarin (SI). Oxidative damage was induced by treating the cells with $0.04 \mathrm{~g} / \mathrm{ml}$ of toxic thioacetamide for 60 minutes followed by treatment with 1,10 and $100 \mu \mathrm{g} / \mathrm{ml}$ concentrations of either PA or SI. The severities of oxidative stress in the control and experimental groups of cells were measured by Malondialdehyde (MDA) levels, superoxide dismutase (SOD), catalase (CAT) and glutathione peroxidase (GPX) activities.
\end{abstract}

Results: PA exhibited an acceptable DPPH scavenging and FRAP activities close to that of Silymarin. Treating the injured cells with PA significantly reduced the MDA level and increased the cell viability, comparable to SI. The activities of SOD, CAT and GPx were significantly elevated in the PA-treated cells in a dose dependent manner and again similar to SI.

Conclusion: Collectively, data suggested that PA has capacity to protect normal liver cells from oxidative damage, most likely via its antioxidant scavenging ability.

Keywords: Cytotoxicity, Hepatocyte, Hepatoprotection, Boesenbergia rotunda, Panduratin A, WRL-68 liver cell line, Oxidative stress

\section{Background}

Boesenbergia rotunda (BR) is a perennial herb belonging to family Zingberaceae and traditionally used as folk medicine for treating diseases such as stomach discomfort, dysentery and leucorrhea in Southeast Asia. Past research have revealed that $\mathrm{BR}$ extract has an anticancer, antibacterial and neuroprotective properties [1-4]. In our previous in vivo experimental study, we have demonstrated that BR extract is hepatoprotective in liver cirrhosis [2]. Treatment of thioacetamide-induced hepatotoxicity with the extract was shown to maintain

\footnotetext{
* Correspondence: mehmet.bilgen@yahoo.com

${ }^{2}$ Biophysics Department, Faculty of Medicine, Erciyes University, 38039,

Kayseri, Turkey

Full list of author information is available at the end of the article
}

normal hepatic architecture and liver function by slowing down the progressive liver damage. Panduratin A (PA) is one of the chalcones present in the BR extract [5] and exhibits anti-inflammatory [5], anti-oxidant [3], antibacterial [6], anti-dengue [7], anti-mutagenic [8] activities. Cheah et al. 2011 reported that $30 \mu \mathrm{M}(12.1 \mu \mathrm{g} / \mathrm{mL})$ dose of PA is cytostatic but not cytotoxic to normal embryonic cell line WRL-68 [9]. Based on these multifunctions of $\mathrm{PA}$, it is plausible that our previous findings on the hepatoprotectivity of the BR extract against liver cirrhosis may in part be due to the presence of this compound in the extract. Therefore, this study was initiated to investigate the hepatoprotective activity of PA when administered alone, specifically in thioacetamideinduced cytotoxicity, with in vitro experiments using 
WRL-68 cell line. In the following, we summarize our experimental procedures, present results and discuss our findings in the context of this objective.

\section{Methods \\ Isolation of the compound Panduratin A from Boesenbergia rotunda extract}

Ethanol based extract was obtained from Boesenbergia rotunda rhizomes (BR) by following the procedures described in our previous paper [2]. Briefly, fresh BR rhizomes were purchased from a company (Ethno Resources Sdn Bhd, Selangor, Malaysia) and identified by comparing against the specimen deposited at the Harbarium of Rimba Ilmu (Voucher number KU0098, Institute of Science Biology, University of Malaya, Kuala Lumpur). After washing the rhizomes with tap water first and then rinsing with distilled water, they were sliced and dried for 10 days. The dry samples were finely grounded, and $100 \mathrm{~g}$ of the resulting powder was mixed in $1000 \mathrm{~mL}$ solution of $95 \%$ ethanol for 7 days at room temperature. The mixture was distilled, and dried at $40^{\circ} \mathrm{C}$ in an incubator for 3 days giving a gummy yield of BR extract at $9.49 \%(\mathrm{w} / \mathrm{w})$. Next, PA was isolated from this product. Specifically, $2.67 \mathrm{~g}$ of the extract sample was dissolved in acetone (Merck AR Grade, Malaysia) and further mixed with $5 \mathrm{~g}$ of silica gel (Silicycle, Ultrapure Silica Gel, Canada). The final mixture was dried using a rotary evaporator. The resulting powder was subjected to column chromatography (CC) containing $47 \mathrm{~g}$ of silica gel. The fractionation/isolation step was based on gradient elution method [10] with the HexaneEthyl acetate (Fisher Scientific AR Grade, UK) solvent system. A total of 11 fractions afforded. A Thin Layer Chromatography (Merck, Silica gel 60 F254, Japan) of the 11 fractions versus PA standard (98\% purity) was carried out at the ratio of 95:5. Fraction BR-3 containing PA $\left(R_{f} 0.29\right)$ was dried using a rotary evaporator and weighed using analytical balance to obtain $0.767 \mathrm{~g}$ pure crystals of PA (96.6\%) as confirmed by High Performance Liquid Chromatography (HPLC) and calculated by the following formula:

$$
\begin{aligned}
\% \text { Purity }= & \text { Peak Area of Panduratin A/ } \\
& (\text { Total Peak Area-Peak Area of Solvent }) .
\end{aligned}
$$

The mass of the isolated PA was determined by LCMS using METLIN DATABASE.

\section{DPPH scavenging activity of Panduratin A}

The antioxidant power of the isolated compound PA was examined first by using 2,2-Diphenyl-1-picrylhydrazyl (DPPH) stable free radical scavenging assay as described by Brand et al. [11], but with a minor modification. The test involved dissolving $1 \mathrm{mg}$ of the compound in $1 \mathrm{ml}$ dimethyl sulfoxide (DMSO) (Fisher Medical, UK) and then further diluting into three different concentrations 1,10 and $100 \mu \mathrm{g} / \mathrm{mL}$. In addition, ascorbic acid and Quercetin were utilized as antioxidant standards and Silymarin was used as an antioxidant reference drug [12]. Amount $(5 \mu \mathrm{L})$ of the compound and the standard were mixed with $195 \mu \mathrm{L}$ of DPPH in triplicate using DMSO as blank. The decrease in absorbance value was assessed at $515 \mathrm{~nm}$ for $2 \mathrm{hr}$ with 20 min gaps. Any antioxidant donates an electron to DPPH and the usual purple hue seen for free DPPH radical decays to yield a change in absorbency. The radical scavenging activity was quantified using the equation:

$$
\begin{aligned}
& \% \text { of fundamental scavenging activity } \\
& =(\text { Abs blank }- \text { Abs sample }) \times 100 / \text { Abs blank } .
\end{aligned}
$$

\section{Ferric reducing power (FRAP) of Panduratin A}

The anti-oxidant power of PA was also determined using a test sensitive to its scavenging ability towards reactive oxygen species or reagents containing iron. In this regard, the ferric reducing anti-oxidant power (FRAP) of the isolated compound was determined using an assay by following the method described in [13], with a slight modification. The FRAP reagent was prepared by mixing $300 \mathrm{mM}$ acetate buffer (3.1 mg sodium acetate/ml, pH 3.6), $10 \mathrm{mM} \mathrm{2,4,6-}$ tripyridyl-S-triazine (TPTZ) (Merck, Darmstadt-Germany) solution [14] and $20 \mathrm{mM} \mathrm{FeCl}{ }_{3} \cdot \mathrm{H}_{2} \mathrm{O}(5.4 \mathrm{mg} / \mathrm{mL})$. Panduratin A compound, and the standards; Ascorbic acid and Quercetin were dissolved in DMSO and sampled in amounts of $10 \mu \mathrm{L}$ of $1 \mu \mathrm{g} / \mathrm{mL}$ along with $10 \mu \mathrm{L}$ of $1 \mu \mathrm{g} / \mathrm{mL}$ silymarin and added into $300 \mu \mathrm{L}$ of the reagent TPTZ separately in triplicate using DMSO as blank. The absorbencies of the resulting mixtures were read using ELISA reader (UV 1601 spectrophotometer, Shimadzu, Kyoto, Japan) at $593 \mathrm{~nm}$ wavelength at 0 minute and after 4 minutes. The readings from the compound and silymarin were compared against the standards; Ascorbic acid and Quercetin [15].

\section{In vitro experiments}

In vitro experiments involved acquiring a hepatic cell line, exposing cells to different concentrations of PA to show that PA is nontoxic, then subjecting the cells to toxicity through thioacetamide (TAA) and finally demonstrating that PA is effective in preventing the death of cells from TAA toxicity.

\section{Cell culture}

Human embryonic normal liver cell line (WRL-68) was originally acquired from American Type Culture Collection ATCC and cultured in our institute. The cells were grown and maintained at $37^{\circ} \mathrm{C}$ by a $5 \% \mathrm{CO} 2$ incubator (NuAire Inc., Plymouth, USA). When needed for 
experiments, normal cells were seeded in 24-well plate with density 3000 cells/well in $200 \mu \mathrm{L}$ of RPMI-1640 containing $10 \% \mathrm{FBS}$ and $1 \%(\mathrm{v} / \mathrm{v})$ penicillin-streptomycin remedy, and incubated at $37^{\circ} \mathrm{C}$ and $5 \% \mathrm{CO} 2$ for 24 hours before starting the experimentation [16].

\section{Determination of the $\mathrm{IC}_{50}$ dose of thioacetamide}

To induce oxidative damage, WRL-68 cells were subjected to a toxic insult by TAA exposure. TAA has a short half-life and is metabolized in the microsomes of hepatocytes [17], but induces cytotoxicity in normal cells $[6,7]$. $\mathrm{IC}_{50}$ denotes inhibition concentration, i.e., concentration of TAA that causes the death of $50 \%$ of the cells. Three different concentrations $0.03,0.04,0.05 \mathrm{~g} / \mathrm{ml}$ of TAA were prepared by dissolving its crystals in sterile distilled water. These three concentrations were selected based on the previous publication, but stated as $\mathrm{g} / \mathrm{mL}$, and indicate amounts which cause oxidative damage to the cells [18]. The cells in three of the four wells were exposed to these concentration amounts by delivery in $10 \mu \mathrm{l}$, as one concentration per well, separately. The unexposed cells in the fourth well again served as control. As shown in results section, $0.04 \mathrm{~g} / \mathrm{ml}$ was determined as the optimum $\mathrm{IC}_{50}$ dose. The percentage of cell viability was calculated by the formula:

$$
\begin{aligned}
\% \text { Cell Viability }= & (\text { Absorbance of the TAA-treated cells } / \\
& \text { Absorbance of sterile distilled water } \\
& \text {-treated cells }) \times 100 .
\end{aligned}
$$

\section{Effects of Panduratin A in TAA-cytotoxicity}

The WRL-68 cells in three of the four wells were treated with $10 \mu \mathrm{L}$ of the optimum IC50 dose $0.04 \mathrm{~g} / \mathrm{mL}$ of TAA. The cells in the fourth well served as normal control group. The cells in all four wells were incubated for one hour and then PA was added in concentrations of 1 , 10 and $100 \mu \mathrm{g} / \mathrm{mL}$, as in the experimentation aimed at determining the cytotoxicity of isolated PA above. The cells were incubated for 24,48 or 72 hours and their viabilities were determined similarly.

Silymarin (SI) is a purified extract and used widely as a supportive therapy for liver disorders such as cirrhosis, hepatitis and fatty acid infiltration due to alcohol or toxic chemicals [14]. We also compared the effects achieved with PA on the TAA-cytotoxicity against the benchmark protection provided by SI $[14,19]$. The concentrations of SI were kept the same as those of PA. Concentrations of 1,10 and $100 \mu \mathrm{g} / \mathrm{mL}$ of SI were respectively delivered to the cells in three separate wells, each in triplicate and their viabilities were evaluated at either 24,48 or 72 hours [20].

\section{Assessment of MDA Level, CAT, SOD and GPx Activities}

The following experiments were conducted to demonstrate the oxidative damage in the cells treated with the PA + TAA or SI + TAA compared to those treated with TAA only through the measurements in the levels of MDA and antioxidant enzymes (CAT, SOD and GPx) $[14,19]$. The cells were seeded and incubated first for one hour with $0.04 \mathrm{~g} / \mathrm{mL}$ TAA and then treated with compounds PA or SI $(1,10,100 \mu \mathrm{g} / \mathrm{mL})$ as mentioned previously. After 72 hours of incubation at $37^{\circ} \mathrm{C}$ and $5 \% \mathrm{CO} 2$, all cells were washed twice with $300 \mu \mathrm{l}$ Phosphate Buffered Saline (PBS), pH 7.4. The cells were detached using a sterilized scrapper and lysed in $25 \mathrm{mmol} / \mathrm{L}$ Tris- $\mathrm{HCl}$ lysis buffer with no protease or phosphatase inhibitors used. The homogenate was thensonicated on ice (10 s pulse) and finally centrifuged at $13000 \mathrm{xg}$ for 15 minutes. The resulting cell lysate was collected and kept at $-20^{\circ} \mathrm{C}$ for assaying CAT, SOD, GPx and MDA following the instructions in the kit manuals of Cayman kits, USA (Cat. \# 707002 for CAT, \# 706002 for SOD, \# 703102 for GPx and \# 10009055 for MDA). Protein concentration in the cell lysate was evaluated using a standard method [21].

\section{Statistical analysis}

All outcomes including the measured concentrations of the proteins CAT, SOD, GPx and MDA were evaluated statistically and the final results were expressed as Mean \pm SEM (standard error in the mean) while $\mathrm{n}=3$. The data were analyzed by one-way analysis (ANOVA) followed by Tukey Post-Hoc test using SPSS (Version 18, SPSS Inc., Chi town, IL, USA). The level of significance was set at $p<0.05$.

\section{Results}

\section{HPLC and LCMS of PA}

Dry pack column chromatography of $B$. rotunda crude extract resulted in 11 fractions. The results of TLC of all fractions versus $\mathrm{PA}$ compound showed that fraction BR-3 contained panduratin A recording retardation factor similar to that of PA standard $\left(R_{f}=0.29\right)$. These results were also confirmed by High performance liquid chromatography (Figure 1a and b). LCMS chromatogram of the isolated PA is illustrated in Figure 1c showing that the compound was detected at $\mathrm{m} / \mathrm{z}$ 407.2211.

\section{DPPH scavenging activity}

Panduratin A compound exhibited comparable free radical scavenging activity for DPPH compared to that of Quercetin (QU) and Ascorbic acid (AC) as shown in (Figure 2) (standard curve equation: $y=1.02333 \times-$ $\left.0.1305, R^{2}=0.9925\right)$. At the highest tested concentrations $100 \mu \mathrm{g} / \mathrm{mL}$, the DPPH inhibition \% of PA was significantly $(P<0.001)$ lower than that of the standards $\mathrm{AC}$ and QU and the reference drug Silymarin. On the other hand, at the lowest tested concentration $1 \mu \mathrm{g} / \mathrm{mL}$, 

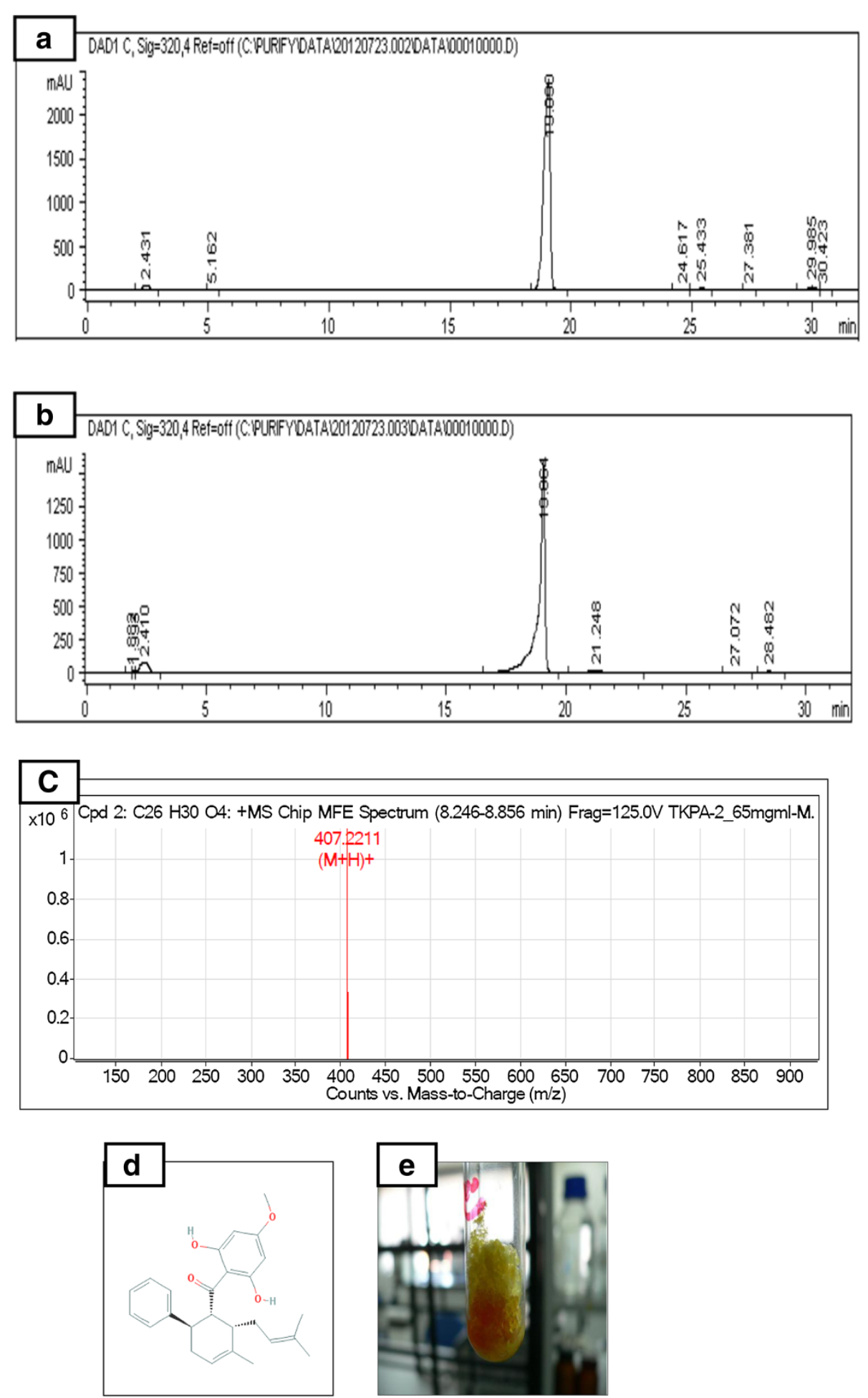

Figure 1 Isolation of Panduratin A compound from the ethanol extract of Boesenbergia rotunda rhizomes. (a) HPLC profile of BR-3 showing Panduratin A compound. (b) HPLC profile of Panduratin A standard. (c) Mass spectrum of Panduratin A. (d) Panduratin A $\left(\mathrm{C}_{26} \mathrm{H}_{30} \mathrm{O}_{4}\right)$ structure. (e) Pale yellow crystals of isolated Panduratin A. 


\section{DPPH free radical scavenging activity}

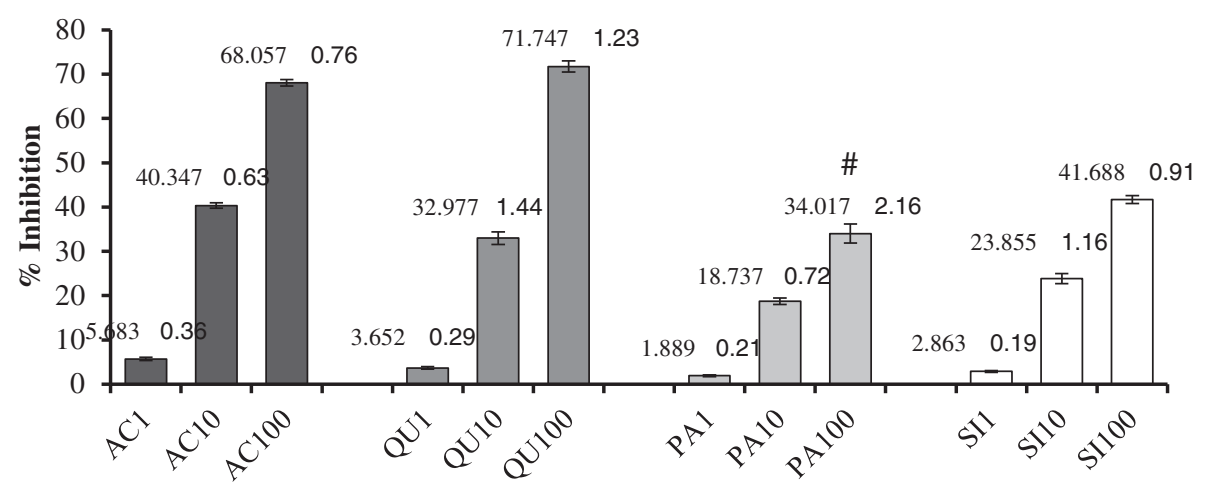

Concentration $\mu \mathrm{g} / \mathrm{mL}$

Figure 2 Percentage inhibition of DPPH scavenging activity of Panduratin A compound (PA) compared with the standards Ascorbic acid (AC) and Quercetin (QU) and the reference drug Silymarin (SI). Values are expressed as Mean \pm SEM, while $n=3 * P<0.001$ compared to AC100 and QU100. ${ }^{\# P}<0.01$ compared to SI100.

there was no significance between PA and the standards $\mathrm{AC}$ and QU or between PA and the standard drug SI. The medium concentration $10 \mu \mathrm{g} / \mathrm{mL}$ revealed low significance $(P<0.001)$ between PA and the standards AC and QU, while the significance detected between PA and SI was $P=0.52$. These results indicated that PA had less potent radical scavenging effect and antioxidant activity than $\mathrm{AC}$ and QU, but similar to that of the reference drug SI at the low and medium concentrations 1 and $10 \mu \mathrm{g} / \mathrm{mL}$, but not at the high concentration $100 \mu \mathrm{g} / \mathrm{mL}$.

\section{FRAP value of PA}

As illustrated in Figure 3, the ferric reducing antioxidant power (FRAP) of Panduratin A was significantly lower $(P<0.01) \quad(1.11 \pm 0.13 \mathrm{mmol} \mathrm{FeII} / \mu \mathrm{g})$ than that of Ascorbic acid and Quercetin (5.37 \pm 0.91 and $19.43 \pm$
$0.74 \mathrm{mmol} F \mathrm{FII} / \mu \mathrm{g}$ respectively), while the standard curve equation recorded $y=0.0006 x+0.624$ and $\mathrm{R} 2=$ 0.9875 . On the other hand, there was no significant difference between the measured FRAP value of Panduratin A and the standard drug Silymarin $(1.72 \pm 0.24 \mathrm{mmol}$ FeII $/ \mu \mathrm{g})$. Further, the results revealed significant decrease in the FRAP value of Silymarin compared to Ascorbic acid $(P<0.01)$ and Quercetin $(P<0.05)$. Based on these readings, it is reasonable to extrapolate that Panduratin A exhibits an acceptable antioxidant activity similar to that of the standard drug Silymarin.

In vitro protective activity of PA against TAA cytotoxicity $I C_{50}$ of TAA

The percentage viability of WRL-68 cells after being incubated with different concentrations of TAA $(0.03,0.04$

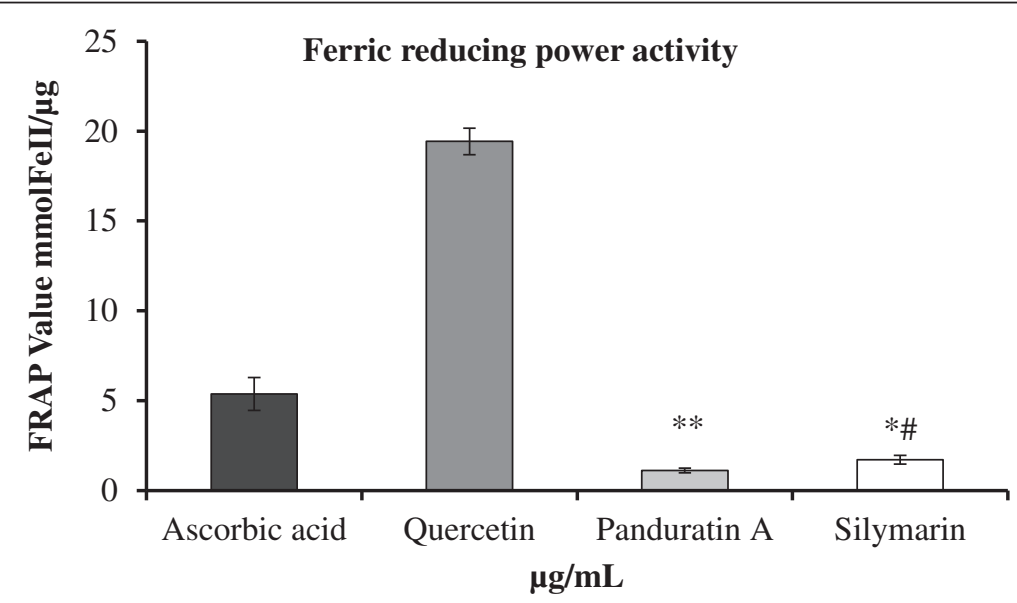

Figure 3 Ferric reducing power (FRAP) of The isolated Panduratin A compound compared with the standards; Ascorbic acid, Quercetin as well as the standard drug Silymarin. Values are expressed as Mean \pm SEM, While $n=3{ }^{*} P<0.01$ compared to Quercetin. ${ }^{* *} P<0.01$ compared to Ascorbic acid and Quercetin. ${ }^{\#} P<0.05$ compared to Ascorbic acid. No significance difference between Panduratin A and Silymarin. 
and $0.05 \mathrm{~g} / \mathrm{mL}$ ) for 30, 60, 90 and $120 \mathrm{~min}$, are illustrated in Figure 4. Results showed that the $\mathrm{IC}_{50}$ dose of TAA is $0.04 \mathrm{~g} / \mathrm{mL}$ at $60 \mathrm{~min}$ of incubation.

\section{Protective effect of PA compound against TAA-toxicity}

The results of treating WRL-68 cells after being incubated for 60 minutes with TAA with three different concentrations of PA and SI compounds are shown in Figure 5. The data showed that, only about $35 \%$ of the untreated cells remained alive at 24,48 or 72 hours after being exposed to TAA. But, treatment of the cells with either PA or SI increased the cell survival significantly to about $90 \%$ irrespective of the dose amount and the measurement time. No significant differences in the percentages of cell viabilities were recorded between the PA or SI treated cells indicating that PA had nearly the same protective effect as SI against TAA-cytotoxicity.

\section{MDA and the antioxidant enzyme CAT, SOD and GPX assays}

As shown in Figure 6, treating WRL-68 cells with $0.04 \mathrm{~g} / \mathrm{mL}$ TAA for 60 minutes markedly elevated the MDA protein level to $14.33 \pm 0.88 \mathrm{nmoL} / \mathrm{mg}$ protein and reduced the antioxidant enzymes CAT, SOD and GP× activities to $4.97 \pm 0.55 \mathrm{nmoL} / \mathrm{min} / \mathrm{mL}, 5.00 \pm 0.58 \mathrm{U} / \mathrm{mL}$ and $7.00 \pm 1.15 \mathrm{nmol} / \mathrm{min} / \mathrm{mL}$, respectively compared to normal control cells (MDA: $6.50 \pm 1.44 \mathrm{nmoL} / \mathrm{mg}$ protein, CAT: $12.67 \pm 0.88 \mathrm{nmoL} / \mathrm{min} / \mathrm{mL}, \quad S O D: 12.83 \pm$ $1.48 \mathrm{U} / \mathrm{mL}$ and GPx: $21.97 \pm 1.18 \mathrm{nmoL} / \mathrm{min} / \mathrm{mL})$. PA treatment was effective towards the restoration of these biomarkers to their normal levels, as the dose increased. The highest dose $100 \mu \mathrm{g} / \mathrm{mL}$ of PA attenuated the protein MDA level back to $7.00 \pm 1.15 \mathrm{nmoL} / \mathrm{mg}$ protein and increased the activities of antioxidant enzymes CAT, SOD and GPx to $13.77 \pm 0.30 \mathrm{nmoL} / \mathrm{min} / \mathrm{mL}, 12.93 \pm$
$1.51 \mathrm{U} / \mathrm{mL}$ and $20.40 \pm \mathrm{nmol} / \mathrm{min} / \mathrm{ml}$, respectively. There was no significant difference between the results obtained from treating the cells with either PA or SI at identical doses, indicating that PA was as effective as SI in protecting the cells against oxidative stress.

\section{Discussion}

Liver cirrhosis is becoming more prevalent in today's modern life as the health medications with side effects are increasingly being used. Consequently, current research targets new counteractive pharmaceutical solutions to tackle with this serious clinical problem [22]. Natural compounds or products extracted from folk medicinal plants are specifically investigated as potential therapeutic sources [23]. Efforts have been focused on evaluating their protective functions, especially with antioxidative impact, and also mechanisms of action in living model systems.

Phenolic substances present in the vegetation are regarded as nutritional antioxidants [24]. Chalcones are groups of phenolic compounds from the flavonoid family and exhibit a range of bioactivities, including anticancer [25] and antioxidative [24]. The anti-oxidant action of chalcones is relevant to various mechanisms such as quenching singlet oxygen, hydrogen atom or electron transfer and act as substrate for superoxide and hydroxide radicals. Anto et al. [26] tested 33 chalcones and chalcone related compounds and reported that most chalcones have high superoxide radical scavenging activity and Yayli et al. [27] confirmed these results. In the present study, the procedure of isolating PA from the ethanolic extract of $B$. rotunda rhizomes could isolate highly purified crystals of the compound and the quantity produced indicates that PA constitutes about 29\% of the plant extract showing acceptable antioxidant \%.

\section{IC50 of TAA}

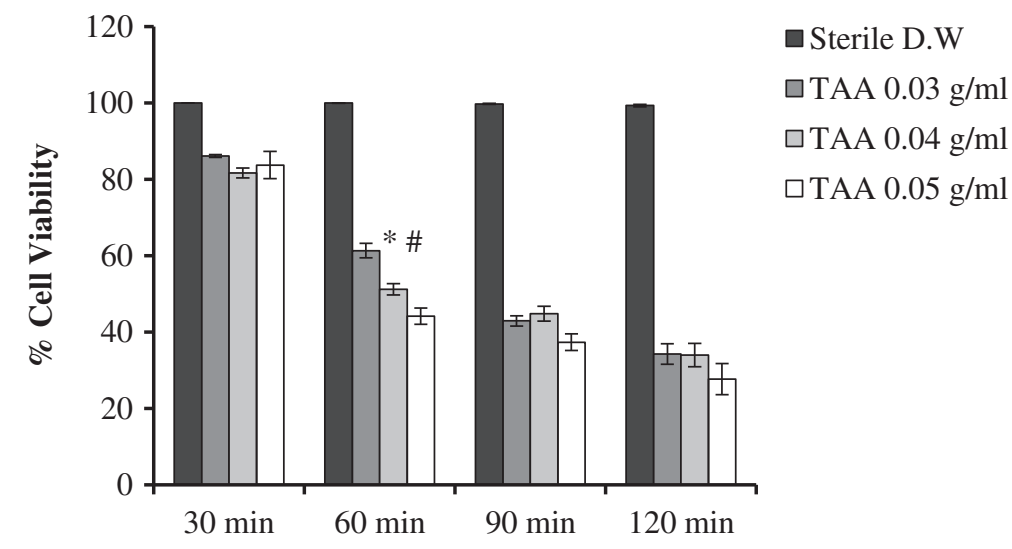

Figure 4 IC 50 of TAA. Data were expressed as Mean \pm SEM, while $\mathbf{n}=3$. ${ }^{*} P<0.05$ compared with TAA-treated cells $(0.03 \mathrm{~g} / \mathrm{ml})$ and ${ }^{\#} P<0.001$ compared with TAA-treated cell $(0.04 \mathrm{~g} / \mathrm{ml})$. D.W: distilled water; TAA: thioacetamide. 


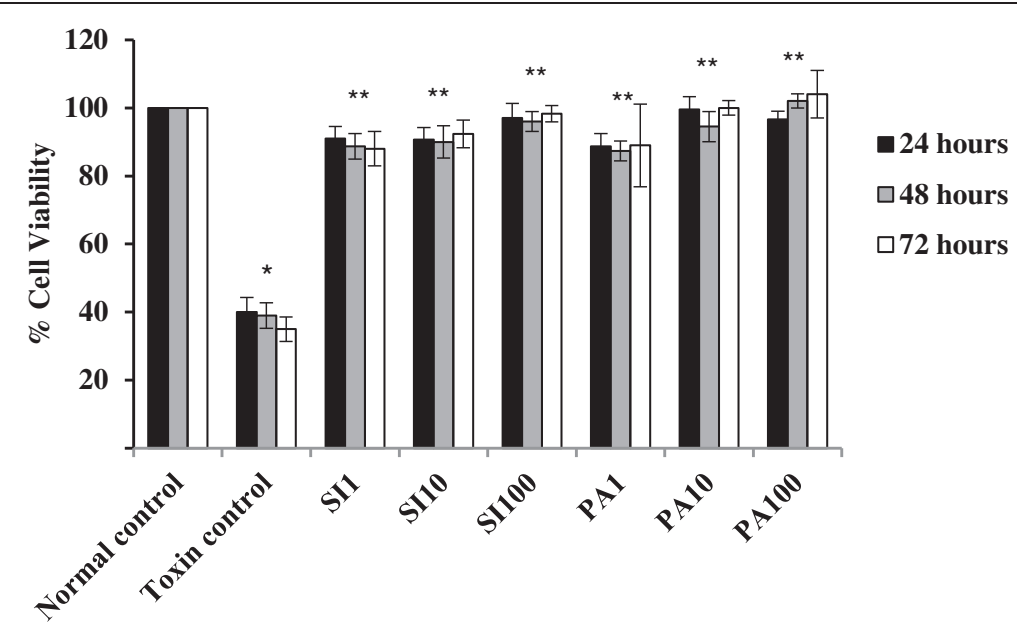

Figure 5 The protective effect of Panduratin A (PA) against TAA toxicity in the WRL-68 cells. Data were expressed as Mean \pm SEM, while $n=3$. Note that the data indicates \% Cell variability exceeding $100 \%$, which means that PA not only protects the cells from the toxic effect of TAA, but also increases the cell proliferation to exceed the number of cells in the normal control.

$\mathrm{DPPH}$ as a stable free radical with structure containing an odd electron, is commonly used in chemical analysis procedures to measure free radical scavenging activity of compounds [28]. Panduratin A is one of the natural chalcones found in Boesenbergia rotunda rhizome extract and it's previously demonstrated favorable biological activities made it attractive for investigating its merits as a potential therapy for the treatment liver cirrhosis in this research. Our results revealed that PA acquired an acceptable \% DPPH inhibition activity

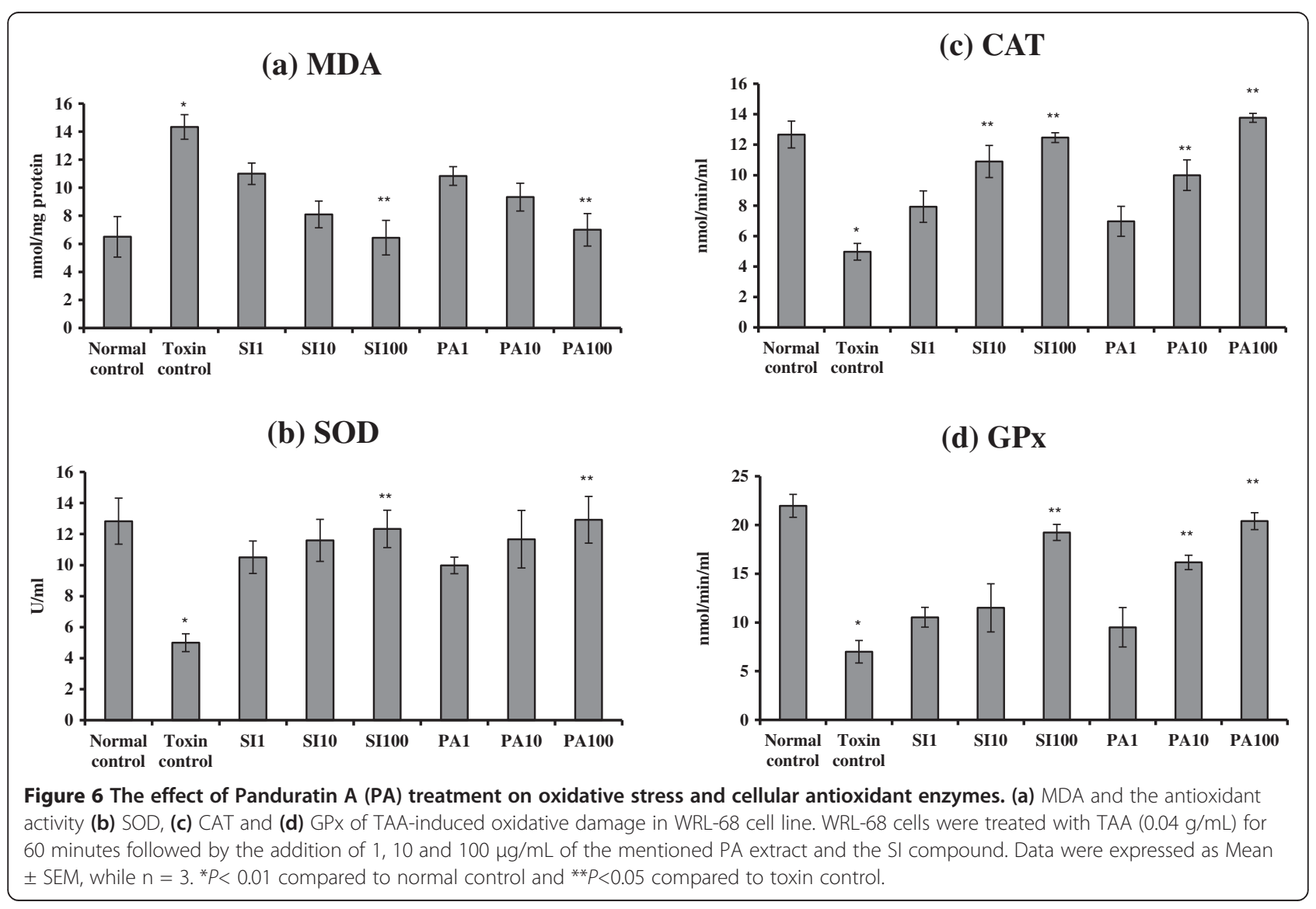


(Figure 2) and ferric reducing power (Figure 3) when compared to the standard reference drugs. This was in line with the known property, i.e. high free radical scavenging activity, of chalcones [29].

Examining the cytotoxicity of Panduratin A on WRL68 cell line revealed that PA was not cytotoxic even at the highest concentration of $100 \mu \mathrm{g} / \mathrm{mL}$. This was in agreement with the findings from PA tests on different cell lines [3] where it was shown that $50 \mu \mathrm{M}(20.3 \mu \mathrm{g} / \mathrm{mL})$ of PA was not toxic.

TAA induces the production of reactive oxygen species (ROS) through its hydrolysis producing $\mathrm{H}_{2} \mathrm{~S}$ as one of the reaction products [30]. Additionally, inside liver cells, $\mathrm{H}_{2} \mathrm{~S}$ cytotoxicity elevates the level of ROS which are normally produced during cellular respiration depleting the level of antioxidant enzymes [31]. but, isolated compounds from plant extracts can effectively protect the hepatocytes from TAA-cytotoxicity [2,18]. Studies with cultured cells have proven the participation of oxidative stress in the etiology of TAA-induced oxidative damage $[14,19]$. TAA triggers fat peroxidation [32]; increases the vulnerability of hepatocytes to fat peroxidation [33]; and decreases the amount of endogenous antioxidant enzymes [34]. We determined that IC50 dose of TAA was $0.04 \mathrm{~g} / \mathrm{mL}$ at $60 \mathrm{~min}$ of incubation with normal hepatocytes (Figure 4). PA treatment increased the viability of the TAA-exposed cells, implicating the protective activity of PA against TAA-cytotoxicity (Figure 5) which can be attributed to PA scavenging activity to ROS.

The hepatoprotective action was also confirmed by the levels of MDA and antioxidant enzymes (CAT, SOD and GPx) (Figure 6). As shown in Figure 6A, the high level of MDA in the cell lysate collected from the toxin control indicated that TAA triggered oxidative damage to cell membranes of liver cells. Fat peroxidation was started by reactive oxygen species (ROS) damaging the unsaturated fatty acids and spread by a chain reaction cycle including fats, lipid hydroperoxides and peroxy radicals [32] altering the cell membrane permeability and resulting in interruption in the structure and function of the membrane. The results of the present study suggest that panduratin A is able to reverse the hepatocyte lipid peroxidation brought on by TAA.

It is well recognized that cellular antioxdant enzymes, the most essential biomolecules defending against oxidative stress [35], can get involved in the decrease of sensitive intermediates. Anti-oxidants which can restrict the production of free radicals are essential with regards to defending the liver cells from toxin-induced damage by counterbalancing the cellular anti-oxidant systems. Whereas, some chalcones were found to inhibit glutathione and glutathione peroxidase (GPx) in hydrogen peroxide $\left(\mathrm{H}_{2} \mathrm{O}_{2}\right)$ induced toxicity in liver cancer cells $\mathrm{HepG}_{2}$ [36], but other chalcones were proved to increase the endogenous cellular enzymes SOD, CAT and GPx in Hydrogen peroxide-oxidative stress in neuroblastoma cells [37]. On the other hand, studies showed that chalcones have efficacy in inhibiting lipid peroxidation [30]. Our research revealed that TAA triggered ROS overproduction and decreased the cellular anti-oxidant enzymes SOD, CAT and GPx in the WRL-68 cells. The data further showed that SOD, CAT and GPx depletion due to TAA was recovered when the damaged cells were treated with panduratin A and the recovery was dosedependent (Figure 6B, C and D). These positive results may be due to free-radical scavenging power of the chalcone PA as assisted by the percentage inhibition of DPPH scavenging activity of PA similarly to the reference drug Silymarin (Figure 2).

\section{Conclusion}

Protecting hepatocytes in vitro from TAA-induced damage seems to be feasible when treated with Panduratin A. But, if the same would hold under in vivo conditions, i.e. if the liver's structure and functions against toxins can be protected with PA, and if PA would play pharmacologic role in liver cirrhosis need further explorations.

\section{Competing interests}

The authors declare that they have no competing interest.

\section{Authors' contributions}

SMS: Designing the research project, collection, analysis, and interpretation of data; writing of the manuscript and the decision to submit the manuscript for publication. AS: Interpretation of data and writing of the manuscript. MAA: Designing the research project and the decision to submit the manuscript for publication. PH: Collection and interpretation of the data. MB: Analysis and interpretation of data, writing and revision of the manuscript. All authors read and approved the final manuscript.

\section{Acknowledgments}

The present study was supported in part by University of Malaya Research Grant PV042-2011A, and UMRG373/11HTM.

\section{Author details}

${ }^{1}$ Department of Molecular Medicine and Biomedical Science, Faculty of Medicine, University of Malaya, 50603, Kuala Lumpur, Malaysia. ${ }^{2}$ Biophysics Department, Faculty of Medicine, Erciyes University, 38039, Kayseri, Turkey.

Received: 22 June 2013 Accepted: 17 October 2013

Published: 24 October 2013

\section{References}

1. Othman R, Kiat TS, Khalid N, Yusof R, Irene Newhouse E, Newhouse JS, Alam $M$, Rahman NA: Docking of noncompetitive inhibitors into dengue virus type 2 protease: understanding the interactions with allosteric binding sites. Journal of chemical information and modeling 2008, 48(8):1582-1591.

2. Salama SM, Bilgen M, Al Rashdi AS, Abdulla MA: Efficacy of boesenbergia rotunda treatment against thioacetamide-induced liver cirrhosis in a Rat model. Evidence-Based Complementary and Alternative Medicine 2012, 2012:12.

3. Shindo $K$, Kato M, Kinoshita A, Kobayashi A, Koike $Y$ : Analysis of antioxidant activities contained in the boesenbergia pandurata schult. Rhizome. Biosci Biotechnol Biochem 2006, 70(9):2281-2284.

4. Voravuthikunchai SP, Phongpaichit S, Subhadhirasakul S: Evaluation of antibacterial activities of medicinal plants widely used among AIDS patients in Thailand. Pharm Biol 2005, 43(8):701-706. 
5. Tuchinda P, Reutrakul V, Claeson P, Pongprayoon U, Sematong T, Santisuk T, Taylor WC: Anti-inflammatory cyclohexenyl chalcone derivatives in boesenbergia pandurata. Phytochemistry 2002, 59(2):169-173.

6. Rukayadi Y, Han S, Yong D, Hwang JK: In vitro antibacterial activity of panduratin A against enterococci clinical isolates. Biol Pharm Bull 2010, 33(9):1489-1493.

7. Kiat TS, Pippen R, Yusof R, Ibrahim H, Khalid N, Rahman NA: Inhibitory activity of cyclohexenyl chalcone derivatives and flavonoids of fingerroot, boesenbergia rotunda (L.), towards dengue-2 virus NS3 protease. Bioorganic \& medicinal chemistry letters 2006, 16(12):3337-3340.

8. Trakoontivakorn G, Nakahara K, Shinmoto H, Takenaka M, Onishi-Kameyama M, Ono H, Yoshida M, Nagata T, Tsushida T: Structural analysis of a novel antimutagenic compound, 4-hydroxypanduratin A, and the antimutagenic activity of flavonoids in a Thai spice, fingerroot (Boesenbergia pandurata Schult.) against mutagenic heterocyclic amines. Journal of agricultural and food chemistry 2001, 49(6):3046-3050.

9. Cheah S-C, Appleton DR, Lee S-T, Lam M-L, Hadi AHA, Mustafa MR: Panduratin A inhibits the growth of A549 cells through induction of apoptosis and inhibition of NF-KappaB translocation. Molecules 2011, 16(3):2583-2598

10. Chan S-A, Chen M-J, Liu T-Y, Fuh M-R, Deng J-F, Wu M-L, Hsieh S-J: Determination of aristolochic acids in medicinal plant and herbal product by liquid chromatography-electrospray-ion trap mass spectrometry. Talanta 2003, 60(4):679-685.

11. Brand-Williams W, Cuvelier M, Berset C: Use of a free radical method to evaluate antioxidant activity. LWT-Food Science and Technology 1995, 28(1):25-30.

12. Polyak SJ, Morishima C, Lohmann V, Pal S, Lee DY, Liu Y, Graf TN, Oberlies $\mathrm{NH}$ : Identification of hepatoprotective flavonolignans from silymarin. Proc Natl Acad Sci 2010, 107(13):5995-5999.

13. Benzie IF, Strain J: The ferric reducing ability of plasma (FRAP) as a measure of "antioxidant power": the FRAP assay. Anal Biochem 1996, 239(1):70-76.

14. Salama SM, Abdulla MA, AlRashdi AS, Ismael S, Alkiyumi SS, Golbabapour S: Hepatoprotective effect of ethanolic extract of Curcuma longa on thioacetamide induced liver cirrhosis in rats. BMC Complement Altern Med 2013, 13(1):56

15. Asghar Z, Masood Z: Evaluation of antioxidant properties of silymarin and its potential to inhibit peroxyl radicals in vitro. Pak J Pharm Sci 2008, 21(3):249-254.

16. Krishnegowda G, Hajjar AM, Zhu J, Douglass EJ, Uematsu S, Akira S, Woods AS, Gowda DC: Induction of proinflammatory responses in macrophages by the glycosylphosphatidylinositols of Plasmodium falciparum. J Biol Chem 2005, 280(9):8606-8616.

17. Chilakapati J, Shankar K, Korrapati MC, Hill RA, Mehendale HM: Saturation toxicokinetics of thioacetamide: role in initiation of liver injury. Drug metabolism and disposition 2005, 33(12):1877-1885.

18. Sarkar MK, Sil PC: Hepatocytes are protected by herb Phyllanthus niruri protein isolate against thioacetamide toxicity. Pathophysiology 2007, 14(2):113-120

19. Salama SM, Abdulla MA, AlRashdi AS, Hadi AHA: Mechanism of hepatoprotective effect of Boesenbergia rotunda in Thioacetamideinduced liver damage in rats. Evidence-Based Complementary and Alternative Medicine 2013, 2013:1-13.

20. Hiraganahalli BD, Chinampudur VC, Dethe S, Mundkinajeddu D, Pandre MK Balachandran J, Agarwal A: Hepatoprotective and antioxidant activity of standardized herbal extracts. Pharmacogn Mag 2012, 8(30):116-123.

21. Lowry $\mathrm{OH}$, Rosebrough NJ, Farr AL, Randall RJ: Protein measurement with the folin phenol reagent. J Biol Chem 1951, 193(1):265-275.

22. Daly AK, Donaldson PT, Bhatnagar P, Shen Y, Pe'er I, Floratos A, Daly MJ, Goldstein DB, John S, Nelson MR: HLA-B\&ast; 5701 genotype is a major determinant of drug-induced liver injury due to flucloxacillin. Nature genetics 2009, 41(7):816-819

23. Khanna D, Sethi G, Ahn KS, Pandey MK, Kunnumakkara AB, Sung B, Aggarwal A, Aggarwal BB: Natural products as a gold mine for arthritis treatment. Curr Opin Pharmacol 2007, 7(3):344-351.

24. Sohn JH, Han KL, Lee SH, Hwang JK: Protective effects of panduratin A against oxidative damage of tert-butylhydroperoxide in human HepG2 cells. Biol Pharm Bull 2005, 28(6):1083-1086.
25. Calliste C-A, Le Bail J-C, Trouillas P, Pouget C, Habrioux G, Chulia A-J, Duroux $\mathrm{J}-\mathrm{L}$ : Chalcones: structural requirements for antioxidant, estrogenic and antiproliferative activities. Anticancer Res 2001, 21(6A):3949-3956.

26. Anto RJ, Sukumaran K, Kuttan G, Rao M, Subbaraju V, Kuttan R: Anticancer and antioxidant activity of synthetic chalcones and related compounds. Cancer Lett 1995, 97(1):33-37.

27. Yayli N, Ucuncu O, Yasar A, Gok Y, Kucuk M, Kolayli S: Stereoselective photochemistry of methoxy chalcones in solution and their radical scavenging activity. Turk J Chem 2004, 28(4):515-521.

28. Bhalodia NR, Nariya PB, Acharya R, Shukla V: Evaluation of in vitro antioxidant activity of flowers of cassia fistula linn. International Journal of PharmTech Research 2011, 3:589-599.

29. Gacche R, Dhole N, Kamble S, Bandgar B: In-vitro evaluation of selected chalcones for antioxidant activity. J Enzyme Inhib Med Chem 2008, 23(1):28-31.

30. Basnar B: Nanopattern Formation Using Dip-Pen Nanolithography. In Tip-Based Nanofabrication. Edited by Tseng AA. New York: Springer; 2011:207-263.

31. Truong DH, Eghbal MA, Hindmarsh W, Roth SH, O'Brien PJ: Molecular mechanisms of hydrogen sulfide toxicity*. Drug Metab Rev 2006, 38(4):733-744

32. Chen LH, Hsu CY, Weng CF: Involvement of P53 and Bax/Bad triggering apoptosis in thioacetamide-induced hepatic epithelial cells. World J Gastroenterol 2006, 12(32):5175-5181.

33. Moronvalle-Halley V, Sacré-Salem B, Sallez V, Labbe G, Gautier J-C: Evaluation of cultured, precision-cut rat liver slices as a model to study drug-induced liver apoptosis. Toxicology 2005, 207(2):203-214.

34. Amali AA, Rekha RD, Lin CJ-F, Wang W-L, Gong H-Y, Her G-M, Wu J-L: Thioacetamide induced liver damage in zebrafish embryo as a disease model for steatohepatitis. J Biomed Sci 2006, 13(2):225-232.

35. Srivastava $M, M a L Q$, Singh $N$, Singh S: Antioxidant responses of hyperaccumulator and sensitive fern species to arsenic. J Exp Bot 2005, 56(415):1335-1342

36. Sikander M, Malik S, Yadav D, Biswas S, Katare DP, Jain SK: Cytoprotective activity of a trans-chalcone against hydrogen peroxide induced toxicity in hepatocellular carcinoma (HepG2) cells. Asian Pac J Cancer Prev 2011, 12:2513-2516

37. Bayati S, Yazdanparast R: Attenuation of lipid and protein oxidation by chalcone derivatives in neuroblastoma cells against $\mathrm{H}_{2} \mathrm{O}_{2}$-induced oxidative stress. Pharmacologyonline 2011, 2:479-489.

doi:10.1186/1472-6882-13-279

Cite this article as: Salama et al.: Protective activity of Panduratin A against Thioacetamide-induced oxidative damage: demonstration with in vitro experiments using WRL-68 liver cell line. BMC Complementary and Alternative Medicine 2013 13:279.

\section{Submit your next manuscript to BioMed Central and take full advantage of:}

- Convenient online submission

- Thorough peer review

- No space constraints or color figure charges

- Immediate publication on acceptance

- Inclusion in PubMed, CAS, Scopus and Google Scholar

- Research which is freely available for redistribution 